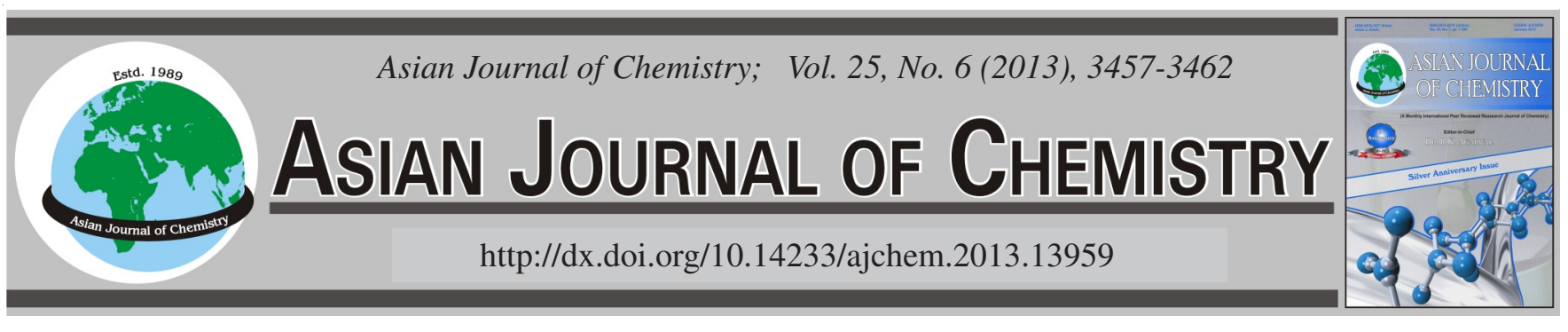

\title{
Spectrophotometric Determination of Cefixime in Pure Form and in Syrian Pharmaceuticals Through Complexation with $\mathrm{Cu}(\mathrm{II})$
}

\author{
Abdul Aziz Ramadan ${ }^{*}$, Hasna Mandil and Marwa DahHan
}

Department of Chemistry, Faculty of Sciences, Aleppo University, Aleppo, Syria

*Corresponding author: Fax: +963 21 2633136; E-mail: dramadan@scs-net.org

\begin{abstract}
Spectroscopic analytical study for the determination of cefixime in pure and its Syrian pharmaceutical formations through complexation with $\mathrm{Cu}(\mathrm{II})$ in acetate buffer at $\mathrm{pH}=7.8$ has been developed. The method is based on the formation pink colour complex between cefixime and $\mathrm{Cu}(\mathrm{II})$. The maximum absorbance of the coloured complex occurred at $\lambda=546 \mathrm{~nm}$ and the molar absorptivity is $3.28 \times 10^{3} \mathrm{~L} \mathrm{~mol}{ }^{-1}$ $\mathrm{cm}^{-1}$. The reaction conditions have been optimized to obtain the complex. Under optimum conditions the absorbance of complex was found to increase linearly with increase in concentrations of cefixime, which corroborated with the correlation coefficient values (1:1). The linear range of the calibration curve was $0.453-9.069 \mu \mathrm{g} \mathrm{mL}^{-1}$ with correlation coefficients $=0.9975$ in all cases. Overall recoveries were of the order of 98.00-101.50\%. The limit of detection and limit of quantification was found to be $0.075 \mu \mathrm{g} \mathrm{mL} \mathrm{and}^{-1} .22 \mu \mathrm{g} \mathrm{mL}$, respectively. The proposed method was simple, economic, accurate and successfully applied to the determination of cefixime in Syrian pharmaceuticals, the results obtained agree well with the contents stated on the labels.

Key Words: Cefixime, Copper(II), Pharmaceuticals, Complex, Spectrophotomety.
\end{abstract}

\section{INTRODUCTION}

Cefixime (CEFI) (6R,7R)-7-[2-(2-amino-4-thiazolyl)glyoxylamido]-8-oxo-3-vinyl-5-thia-1-azabicyclo [4.2.0]oct-2ene-2-carboxylic acid, 7-(Z)-[o-(carboxymethyl)oxime] trihydrate is third-generation cephalosporin antibiotic ${ }^{1}$ (Fig. 1).

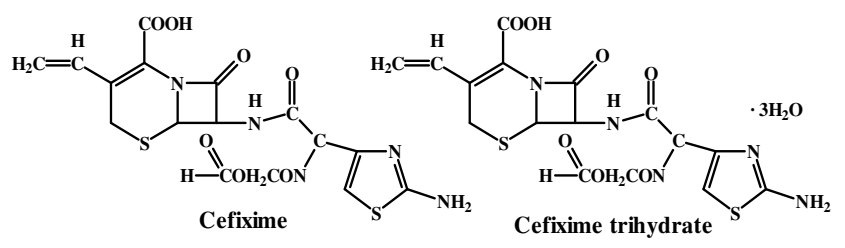

Fig. 1. Scheme of cefixime and cefixime trihydrate

Cephalexin, cefixime, ceftriaxone and cefotaxime were determined spectrophotometrically in the pure form and in pharmaceutical formulations by using ferrihydroxamate method. Using cefotaxime sodium as model drug with ester functional group, it was shown that proposed method gives equally accurate and precise results even in the presence of ester functional group ${ }^{2}$.

A simple and sensitive spectrophotometric method has been developed for the determination of five cephalosporins namely cefpodoxime, ceftizoxime, ceftazidime, ceftriaxone and cefixime. This method is based on the formation of yellow to yellowish brown complex between palladium(II) chloride and the investigated cephalosporins in the presence of sodium lauryl sulphate as surfactant. The reaction conditions were studied and optimized. The procedure was validated. The proposed method was used for the determination of the above-mentioned drugs in their commercial preparations. The results were compared statistically with either official or published methods and showed no significant difference between the two methods ${ }^{3}$.

A sensitive, accurate and rapid flow injection analysis method for the determination of cefotaxime, cefuroxime, ceftriaxone, cefaclor, cefixime, ceftizoxime and cephalexin is proposed. Aliquots of each cephalosporin were hydrolyzed for 15 min with $0.1 \mathrm{M} \mathrm{NaOH}$ at $80^{\circ} \mathrm{C}$ and then oxidized with $\mathrm{Fe}^{3+}$ in sulfuric acid medium to produce $\mathrm{Fe}^{2+}$. The produced $\mathrm{Fe}^{2+}$ is then complexed by o-phenanthroline (o-phen) in citrate buffer at $\mathrm{pH} 4.2$ to form the red complex, $\mathrm{Fe}(o \text {-phen })_{3}{ }^{2+}$, which exhibits an absorption maximum at $510 \mathrm{~nm}$. The method was successfully applied to the analysis of pharmaceutical preparations. The results have been compared with those obtained using the official methods. Excellent agreement between the results of the proposed method and the official methods was obtained $^{4}$.

Two spectrophotometric methods have been developed for the determination of cefixime in pure and in its pharmaceutical 
formulations. In UV method cefixime showed absorption maximum at $290 \mathrm{~nm}$. in aqueous medium, where as in visible spectrophotometric method it reacts with Folin-Ciocalteu (FC) reagent under alkaline conditions forming a blue coloured chromogen having absorption maximum at $720 \mathrm{~nm}$. These methods obey Beer's law in the concentration range of 1 to 15

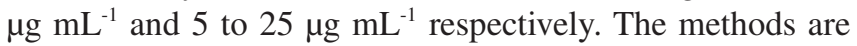
statistically evaluated for accuracy and precision ${ }^{5}$.

Three simple and sensitive spectrophotometric, difference spectroscopic and liquid chromatographic (LC) methods are described for the determination of cefixime. The first method is based on the oxidative coupling reaction of cefixime with 3-methyl-2-benzothiazolinone hydrazone hydrochloride in presence of ferric chloride. The absorbance of reaction product was measured at the maximum absorbance wavelength $\left(\lambda_{\max }\right)$, $630 \mathrm{~nm}$. The difference spectroscopic method is based on the measurement of absorbance of cefixime at the absorbance maximum, $268 \mathrm{~nm}$ and minimum, $237 \mathrm{~nm}$. The measured value was the amplitude of maxima and minima between 2 equimolar solutions of the analyte in different chemical forms, which exhibited different spectral characteristics. The conditions were optimized and Beer's law was obeyed for cefixime at 1 to 16 $\mu \mathrm{g} \mathrm{mL} \mathrm{m}^{-1}$ and 10 to $50 \mu \mathrm{g} \mathrm{mL} \mathrm{m}^{-1}$, respectively. The third method, high-performance liquid chromatographic, was developed for the determination of cefixime using $50 \mathrm{mM}$ potassium dihydrogen phosphate ( $\mathrm{pH} 3.0)$ methanol $(78 / 22$, v/v) as the mobile phase and measuring the response at $\lambda_{\max } 286 \mathrm{~nm}$. The analysis was performed on a Lichrospher $\mathrm{RPC}_{18}$ column. The calibration curve was obtained for cefixime at 5 to $250 \mu \mathrm{g}$ $\mathrm{mL}^{-1}$ and the mean recovery was $99.71 \pm 0.01 \%$. The methods were validated according to the guidelines of the U.S. Pharmacopoeia and also assessed by applying the standard addition technique. The results obtained in the analysis of dosage forms agreed well with the contents stated on the labels ${ }^{6}$.

A simple, precise and accurate kinetic spectrophotometric method for determination of cefradine anhydrous, cefaclor monohydrate, cefadroxil monohydrate, cefalexin anhydrous and cefixime in bulk and in pharmaceutical formulations has been developed. The method based on a kinetic investigation of the reaction of the free carboxylic acid group of the drug with a mixture of potassium iodate and potassium iodide at room temperature to form yellow coloured triiodide ions. The reaction was followed up spectrophotometrically by measuring the increase in absorbance at $352 \mathrm{~nm}$ as a function of time. The initial rate, fixed time, variable time and rate-constant methods were adopted for constructing the calibration curves but fixed time method has been found to be more applicable. The method has been successfully applied to the determination of the studied drugs in commercial pharmaceutical formulations ${ }^{7}$.

A simple, accurate and precise spectrophotometric method has been proposed for the determination of 11 cephalosporins, namely; cefaclor monohydrate, cefadroxil monohydrate, cefalexin anhydrous, cefradine anhydrous, cefotaxime sodium, cefoperazone sodium, ceftriaxone sodium, ceftazidime penthydrate, cefazolin sodium, cefixime and cefpodoxime proxetil in bulk drug and in pharmaceutical formulations. The method depends on hydrolysis of the studied drugs using
$0.5 \mathrm{M} \mathrm{NaOH}$ at $100^{\circ} \mathrm{C}$ and subsequent reaction of the formed sulfide ions with NBD-Cl (4-chloro-7-nitrobenzo-2-oxa-1,3diazole) to form a yellow-coloured chromogen measured at $390 \mathrm{~nm}$. Under the optimum conditions, linear relationships with good correlation coefficients (0.9990- 0.9999) were found in the range of 5-160 $\mu \mathrm{g} \mathrm{mL}^{-1}$ for all studied drugs. The limits of assay detection and quantitiation ranged from 0.289 to 5.867 and from 0.878 to $17.778 \mu \mathrm{g} \mathrm{mL}^{-1}$; respectively. The method was successfully applied for analysis of the studied drugs in their pharmaceutical formulations and the recovery percentages ranged from 96.6 to $103.5 \%$.

A simple specrtophotometric method for the determination of cefoxamide with variamine blue is presented. The determination is based on the hydrolysis of $\beta$-lactum ring of cefixime with sodium hydroxide which subsequently reacts with iodate to liberate iodine in acidic medium. The liberated iodine oxidizes variamine blue to violet coloured species of maximum absorption at $572 \mathrm{~nm}$. The absorption is measured within the $\mathrm{pH}$ range of 4.0-4.2. Beer's law is obeyed in the range of 0.5$5.9 \mu \mathrm{g} \mathrm{mL}{ }^{-1}$ for cefixime. The analytical parameter was optimized and the method is successfully applied for the determination of cefixime ${ }^{9}$.

An accurate and precise colourimetric method is presented for the determination of ofloxacin and cefixime in same pharmaceutical formulation. Ofloxacin forms an orange coloured product in the presence of ferric chloride solution in acidic medium and the absorbance of orange coloured species formed was measured at $435 \mathrm{~nm}$ against reagent blank and Beer's law was obeyed in the concentration range of 15-75 $\mu \mathrm{g}$ $\mathrm{mL}^{-1}$. While cefixime forms a greenish coloured product with Fehling solution and the absorbance of greenish coloured species formed was measured at $490 \mathrm{~nm}$ against reagent blank and Beer's law was obeyed in the concentration range of 5-40 $\mu \mathrm{g} \mathrm{mL} \mathrm{L}^{-1}$. The amount of cefixime and ofloxacin present in the sample was computed from calibration curve. It is also found that there is no interference of cefixime while estimation of ofloxacin and vice versa ${ }^{10}$.

A simple, sensitive and accurate method has been developed for spectrofluorimetric determination of cefixime in pure form and pharmaceutical preparations. The method is based on the reaction of cefixime with 2-cyanoacetamide in the presence of $21 \%$ ammonia at $100{ }^{\circ} \mathrm{C}$. The fluorescent reaction product showed maximum fluorescence intensity at $\lambda 378$ $\mathrm{nm}$ after excitation at $\lambda 330 \mathrm{~nm}$. The factors affecting the derivatization reaction were carefully studied and optimized. The fluorescence intensity versus concentration plot was rectilinear over the range of 0.02 to $4 \mu \mathrm{g} \mathrm{mL}^{-1}$ with correlation coefficient of 0.99036 . The limit of detection and limit of quantification was found to be $2.95 \mathrm{ng} \mathrm{mL}^{-1}$ and $9.84 \mathrm{ng} \mathrm{mL}^{-1}$, respectively. The proposed method was validated statistically and through recovery studies. The method was successfully applied for the determination of cefixime in pure and dosage form with percent recoveries from $98.117 \%$ to $100.38 \%$. The results obtained from the proposed method have been compared with the official HPLC method and good agreement was found between them ${ }^{11}$.

A simple, sensitive, rapid, accurate, precise and economic dual wavelength spectrophotometric method was developed 
for the simultaneous determination of cefixime trihydrate (CEFI) and ofloxacin (OFLO) in combined tablet dosage form. The method was based on determination of ofloxacin at 350 $\mathrm{nm}$ using its absorptivity value and cefixime at $264 \mathrm{~nm}$ after deduction of absorbance due to ofloxacin. The two drugs follow Beer-Lambert's law over the concentration range of 2-14 $\mu \mathrm{g}$ $\mathrm{mL}^{-1}$. The method was successfully applied to pharmaceutical dosage form because no interference from the tablet excipients was found. The results of analysis have been validated statistically and by recovery studies ${ }^{12}$.

A simple, sensitive, rapid, accurate, precise and economical Q-absorbance ratio method for the simultaneous determination of cefixime trihydrate and ofloxacin in combined tablet dosage form. Absorbance ratio method uses the ratio of absorbances at two selected wavelengths, one which is an isoabsorptive point and other being the $\lambda_{\max }$ of one of the two components. Cefixime trihydrate and ofloxacin show an isoabsorptive point at $280.2 \mathrm{~nm}$ in methanol. The second wavelength used is 291.4 $\mathrm{nm}$, which is the $\lambda_{\max }$ of cefixime trihydrate in methanol. The linearity was obtained in the concentration range of 2-14 $\mu \mathrm{g}$ $\mathrm{mL}^{-1}$ for both cefixime trihydrate and ofloxacin. The concentrations of the drugs were determined by using ratio of absorbances at isoabsorptive point and at the $\lambda_{\max }$ of cefixime trihydrate. The method was successfully applied to pharmaceutical dosage form because no interference from the tablet excipients was found ${ }^{13}$.

A new, simple, sensitive and accurate spectrophotometric method has been developed for the assay of metoprolol tartrate (MPT), which is based on the complexation of drug with copper(II) at pH 6.0, using Britton-Robinson buffer solution, to produce a blue adduct. The latter has a maximum absorbance at $675 \mathrm{~nm}$ and obeys Beer's law within the concentration range 8.5-70 $\mu \mathrm{g} \mathrm{mL}^{-1}$. Regression analysis of the calibration data showed a good correlation coefficient $(r=0.998)$ with a limit of detection of $5.56 \mu \mathrm{g} \mathrm{mL} \mathrm{m}^{-1}$. The proposed procedure has been successfully applied to the determination of this drug in its tablets. In addition, the spectral data and stability constant for the binuclear copper(II) complex of metoprolol tartrate $\left(\mathrm{Cu}_{2} \mathrm{MPT}_{2} \mathrm{Cl}_{2}\right)$ have been reported ${ }^{14}$.

A new simple, accurate and cost-effective spectrophotometric method has been developed for the analysis of some cephalosporins (ceftriaxone, ceftazidime, cefixime, cefotaxime and cefuroxime) in bulk samples and pharmaceutical dosage forms. The reaction involves a two-step process of diazotization of the cephalosporins with acidified $\mathrm{NaNO}_{2}$ at $0-5^{\circ} \mathrm{C}$ and coupling with acidified $p$-dimethylaminobenzaldehyde (DMAB). Beer's law was obeyed at concentrations ranging from 5 to $60 \mu \mathrm{g} \mathrm{mL}^{-1}$ with correlation coefficients $>0.9980$ in all cases. Overall recoveries were of the order of 95-103\% with errors generally less than $6 \%$. The method was successfully applied to the determination of the cephalosporins in dosage forms and it was found to be equivalent accuracy to the official (USP and BP) HPLC assay procedures for these drugs. There was no interference from commonly adopted excipients. The method could find application as a rapid and cost-effective alternative for the quality control of these cephalosporins, especially in preliminary studies ${ }^{15}$.

An accurate, precise and ecofriendly spectrophotometric method is presented for the determination of cefixime based on the formation of a yellow colour product with ninhydrin in the presence of bicarbonate with an absorption maximum at $438 \mathrm{~nm}$. The reaction proceeds quantitatively at $97 \pm 1{ }^{\circ} \mathrm{C}$ in $15 \mathrm{~min}$. The calibration curve is linear over the range of 45-65 $\mu \mathrm{g} \mathrm{mL}{ }^{-1}$ with a regression coefficient ( $\mathrm{r}$ ) of $0.9987(\mathrm{n}=5)$. The calculated molar absorptivity and Sandell sensitivity values are $4.1536 \times 10^{3} \mathrm{~L} \mathrm{~mol}^{-1} \mathrm{~cm}^{-1}$ and $0.0072 \mu \mathrm{g} / \mathrm{cm}^{2}$, respectively. The limits of detection and quantification calculated as per ICH guidelines are 1.13 and $3.40 \mu \mathrm{g} \mathrm{mL}^{-1}$, respectively. Accuracy was also checked by placebo blank and synthetic mixture analyses besides a recovery study via standard addition procedure ${ }^{16}$.

In the present work, spectroscopic analytical study for the analysis of cefixime in pure and its Syrian pharmaceutical formations through complexation with $\mathrm{Cu}$ (II) in acetate buffer has been applied.

\section{EXPERIMENTAL}

Spectrophotometric measurements was made in a Biotech E.M. UV-Visible spectrophotometer with $1.00 \mathrm{~cm}$ quartz cells. The $\mathrm{pH}$ measurement was performed with EUTECH COPERSCAN-500. A ultrasonic processor model POWERSONIC 405 was used to sonicate the sample solutions. The solution was kept in a thermostat at $30^{\circ} \mathrm{C}$. The diluter pipette model DIP-1 (Shimadzu), having $100 \mu \mathrm{L}$ sample syringe and five continuously adjustable pipettes covering a volume range from 20 to $5000 \mu \mathrm{L}$ (model PIPTMAN P, GILSON), were used for preparation of the experimental solutions.

Cefixime trihydrate $(99.0 \%$ ) was of pure from Parabolic Drugs-India, the purity $88.6 \%$ as cefixime, which was determined by HPLC method ${ }^{6}$. Copper chloride dihydrate, sodium acetate, acetic acid and all other reagents were of analytical grade and alcohols were of extra pure from Merck. A stock solution (a) $2.5 \times 10^{-3} \mathrm{~mol} \mathrm{~L}^{-1}\left(1.1336 \mathrm{mg} \mathrm{mL}^{-1}\right)$ and stock solution (b) $2.5 \times 10^{-4} \mathrm{~mol} \mathrm{~L}^{-1}\left(113.36 \mu \mathrm{g} \mathrm{mL} \mathrm{mL}^{-1}\right)$ of cefixime were prepared in methanol. A stock solution (c) $2.5 \times 10^{-2} \mathrm{~mol}$ $\mathrm{L}^{-1}$ and stock solution (d) $2.5 \times 10^{-5} \mathrm{~mol} \mathrm{~L}^{-1}$ of $\mathrm{Cu}$ (II) were prepared in distillated water. A acetate buffer solution $(0.4$ mol L $\left.{ }^{-1}\right)$ was prepared in methanol- distillated water $(1: 1)$.

Sample preparation: A commercial formulations (tablet and capsule) were used for the analysis of cefixime by using spectrophotometric analysis. The pharmaceutical formulations were used as the follows: Bioxime, Shifa pharmaceutical industries-Aleppo-Syria, each tablet contains: $400 \mathrm{mg}$ cefixime; Cefix, Alpha, Aleppo pharmaceutical industries-Aleppo-Syria, Each capsule contains: $400 \mathrm{mg}$ cefixime; Cifime (capsule), Delta for medicaments-Aleppo-Syria, each capsule contains: 400 mg cefixime, Supraxime, Asia pharmaceutical industriesAleppo-Syria and cifime (tablet), Delta for medicamentsAleppo-Syria, each tablet contains: $200 \mathrm{mg}$ cefixime. Crushed three tablets (or the contents of three capsules) of each studied pharmaceutical formulations, mix well and weigh equivalent tenth the weight of one tablet (or content one capsule), solve it in $40 \mathrm{~mL}$ methanol by using ultrasonic, filtered over a 50 $\mathrm{mL}$ flask and diluting to $50 \mathrm{~mL}$ with methanol (stock solution of pharmaceutical formulations). For stock solutions content: 40, 40, 40 and $20 \mu \mathrm{g} / 50 \mathrm{~mL}$ of cefixime for pharmaceuticals: bioxime, cefix, cifime (capsule), supraxime and cifime (tablet) 
respectively. Working solutions of pharmaceuticals were prepared daily by diluting $0.050 \mathrm{~mL}$ from stock solution of pharmaceutical formulations and $2.00 \mathrm{~mL}$ from stock solution (c) of $\mathrm{Cu}$ (II) and diluting to $25 \mathrm{~mL}$ with acetate buffer [working solution of bioxime, cefix, cifime (capsule), Supraxime and Cifime (tablet) content: 1.60, 1.60, 1.60, 1.60 and $0.80 \mu \mathrm{g}$ $\mathrm{mL}^{-1}$ cefixime, respectively]. Working standard addition solutions of pharmaceuticals were prepared as the follows: same mentioned volumes of stock solutions of pharmaceuticals and $2.00 \mathrm{~mL}$ stock solution (c) of $\mathrm{Cu}$ (II) with $0.100,0.200$, $0.400,0.800$ and $1.000 \mathrm{~mL}$ from stock solution (b) of cefixime and diluting to $25 \mathrm{~mL}$ with acetate buffer.

Procedure: A $25 \mathrm{~mL}$ volume of a solution containing an appropriate concentration of cefixime and $\mathrm{Cu}$ (II) with acetate buffer (or working solutions of pharmaceuticals or working standard addition solutions of pharmaceuticals) at $\mathrm{pH} 7.8$ and temperature at $30 \pm 1{ }^{\circ} \mathrm{C}$ in $45-60$ min with an absorption maximum at $546 \mathrm{~nm}$ be ready for measurement.

\section{RESULTS AND DISCUSSION}

The different experimental parameters affecting the produced colour of cefixime: $\mathrm{Cu}$ (II) complex were extensively studied in order to determine the optimal conditions for the determination of cefixime.

Spectrophotometric results: UV-VIS spectra by using acetate buffer of $\mathrm{pH} 7.8$ as blank were studied. The cefixime solutions do not absorb in range 220-650 nm while have two maximum absorbance at $\lambda=290 \mathrm{~nm}$ and at $240 \mathrm{~nm}$, the molar absorptivity are $2.29 \times 10^{4}$ and $1.60 \times 10^{4} \mathrm{~L} \mathrm{~mol}^{-1} \mathrm{~cm}^{-1}$, respectively. The $\mathrm{Cu}$ (II) solutions has absorption only at $245 \mathrm{~nm}$, the molar absorptivity are $3.96 \times 10^{3} \mathrm{~L} \mathrm{~mol}^{-1} \mathrm{~cm}^{-1}$. When the cefixime: $\mathrm{Cu}(\mathrm{II})$ complex solutions has absorption at $546 \mathrm{~nm}$, the molar absorptivity are $3.28 \times 10^{3} \mathrm{~L} \mathrm{~mol}^{-1} \mathrm{~cm}^{-1}$ (Fig. 2).

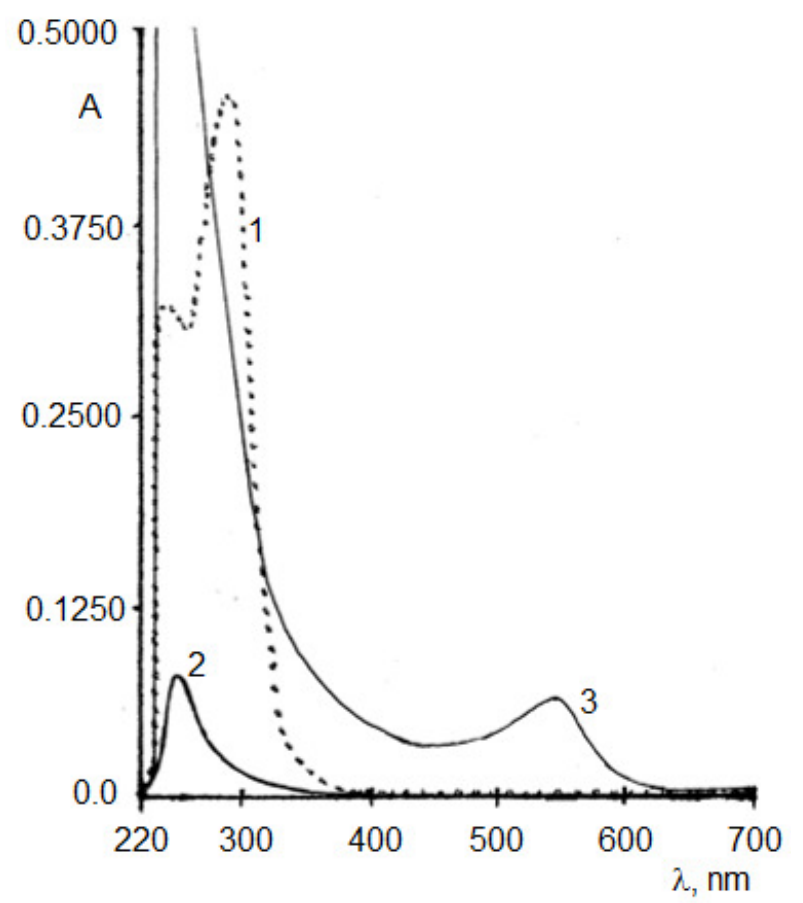

Fig. 2. UV-VIS spectra of: 1) $2 \times 10^{-5} \mathrm{M}$ cefixime, 2) $\left.2 \times 10^{-5} \mathrm{M} \mathrm{Cu}(\mathrm{II}), 3\right) 2$ $\times 10^{-5} \mathrm{M}$ complex; $\left[2 \times 10^{-5} \mathrm{M}\right.$ cefixime with $\left.1 \times 10^{-3} \mathrm{M} \mathrm{Cu}(\mathrm{II})\right]$ (in acetate buffer at $\mathrm{pH}=7.8 ; \ell=1 \mathrm{~cm}$ )
Effect of pH: First, the influence of $\mathrm{pH}$ on the absorption was studied. The maximum absorption using acetate buffer occurs at approximately $\mathrm{pH} 7.8$.

Effect of temperature: The effect of temperature on the produced adduct was studied. it was found that heating at $30^{\circ} \mathrm{C}$ was better than heating at a higher temperature.

Effect of time: The effect of time on formation of complex was studied. It was found that better time was 40-60 min.

Effect of buffer and solvent: The better buffer was sodium acetate and the better solvent was methanol: distillated water (1:1).

Effect of concentration of $\mathbf{C u}(\mathbf{I I})$ : The effect of concentration of $\mathrm{Cu}$ (II) on formation of complex was studied. It was found that better concentration was more than 10 times of concentration cefixime.

Composition of cefixime: $\mathbf{C u}$ (II) complex: The composition of cefixime: $\mathrm{Cu}(\mathrm{II})$ complex was determined by Job's method of continuous variation method as follows:

Molar ratio method: The stoichiometry of cefixime: $\mathrm{Cu}$ (II) complex by molar ratio method according to following equation: $A_{\max }=f([\mathrm{Cu}(\mathrm{II})] /[$ cefixime $]$, confirms that the ratio of complex cefixime: $\mathrm{Cu}(\mathrm{II})$ is equal to $1: 1$. Where the concentration of cefixime is constant $\left(1 \times 10^{-4} \mathrm{M}\right)$ and the concentrations of $\mathrm{Cu}(\mathrm{II})$ is change from 0 to $2 \times 10^{-4} \mathrm{M}$ (Figs. 3 and 4). Fig. 3 shoed that, UV-visible spectra have two isosbestic points at $314 \mathrm{~nm}$ and at $274 \mathrm{~nm}$.

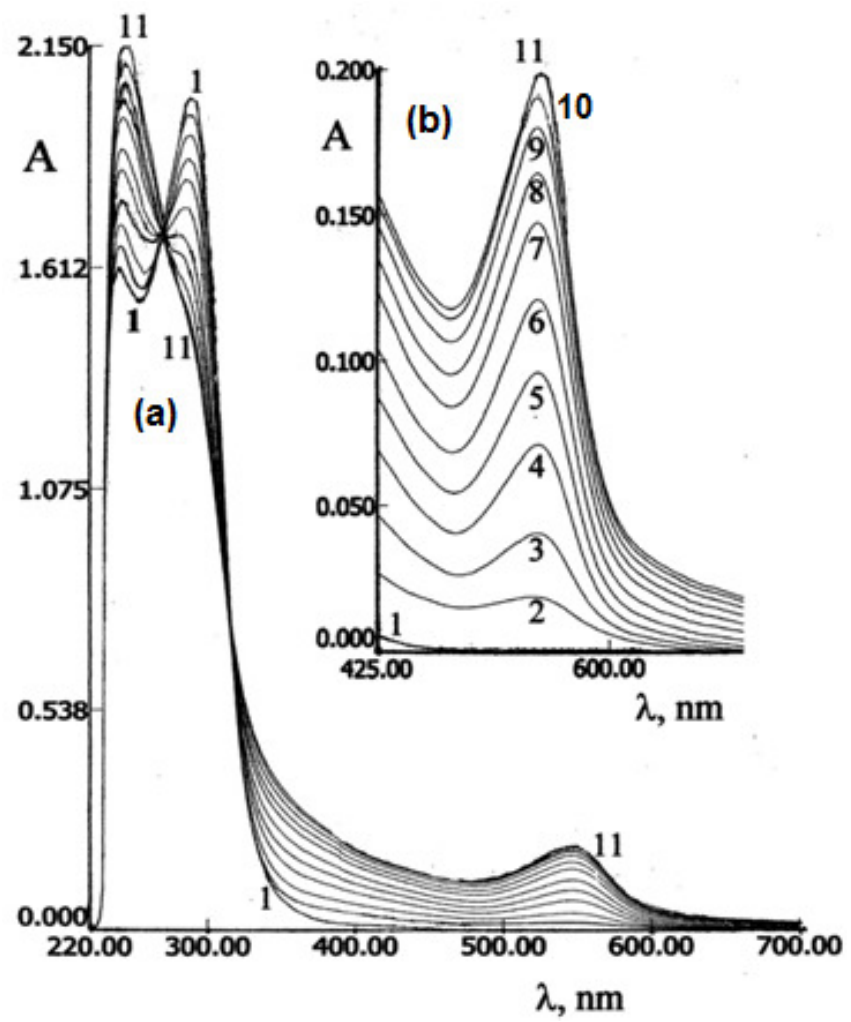

Fig. 3. UV-VIS spectra of $1 \times 10^{-4} \mathrm{M}$ cefixime with $\mathrm{Cu}(\mathrm{II}) ; 0$ to 11 concentration of $\mathrm{Cu}(\mathrm{II})$ were as the followas: 1) 0 ;2) $1.67 \times 10^{-5}$; 3) $3.33 \times 10^{-5}$; 4) $5.00 \times 10^{-5}$; 5) $6.67 \times 10^{-5}$; 6) $8.33 \times 10^{-5}$; 7) $1.00 \times$ $10^{-4}$; 8) $1.25 \times 10^{-4}$; 9) $1.50 \times 10^{-4}$; 10) $1.75 \times 10^{-4}$; 11) $2.00 \times 10^{-4}$ $\mathrm{M}$ (in acetate buffer at $\mathrm{pH}=7.8 ; \ell=1 \mathrm{~cm}$ )

Calibration curve: The calibration curves for cefixime in pure form through complexation with $\mathrm{Cu}(\mathrm{II})$ \{cefixime: 
$\mathrm{Cu}(\mathrm{II})$ complex showed excellent linearity over concentration ranges of 0.453-9.069 $\mu \mathrm{g} \mathrm{mL}^{-1}$, see Fig. 5. The spectra characteristics of the cefixime: $\mathrm{Cu}(\mathrm{II})$ solutions as $\varepsilon, \lambda_{\max }$, Beer's law, the equation $(\mathrm{y}=0.00706 \mathrm{x}+0.00021 ; \mathrm{y}=$ absorbance, $\mathrm{x}=$ concentration of cefixime in $\mu \mathrm{g} \mathrm{mL}^{-1}, 0.00021=$ intercept and $0.00706=$ slope $)$ and the correlation coefficient $\left(R^{2}=0.9982\right)$ are summarized in Table- 1 .

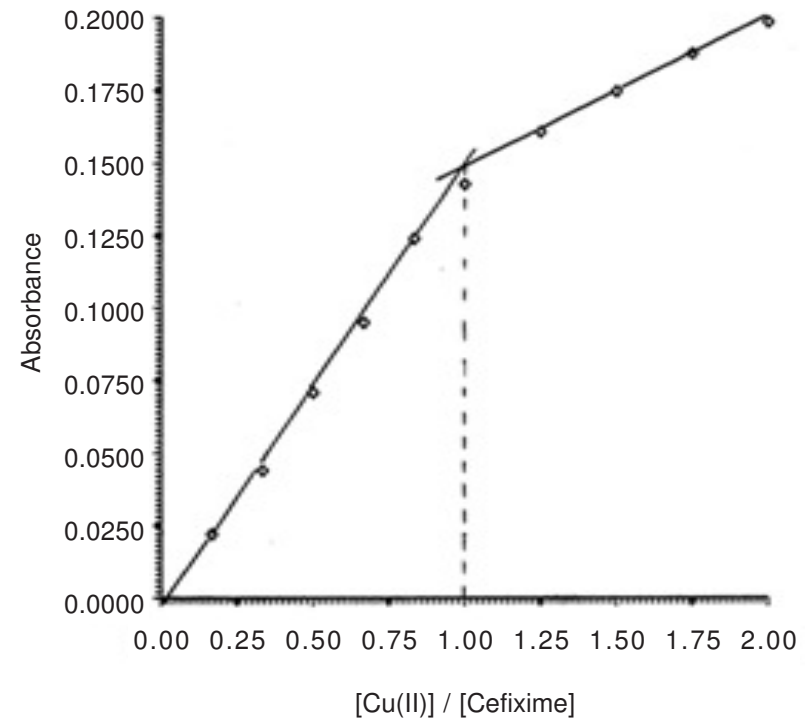

Fig. 4. Molar ratio method to calculate coupling ratio for cefixime: $\mathrm{Cu}(\mathrm{II})$ complex (by using acetate buffer of $\mathrm{pH} 7.8$ as blank, $\mathrm{C}_{\text {cefixime }}=1 \times$ $\left.10^{-4} \mathrm{M}, \ell=1 \mathrm{~cm}, \lambda_{\max }=546 \mathrm{~nm}\right)$

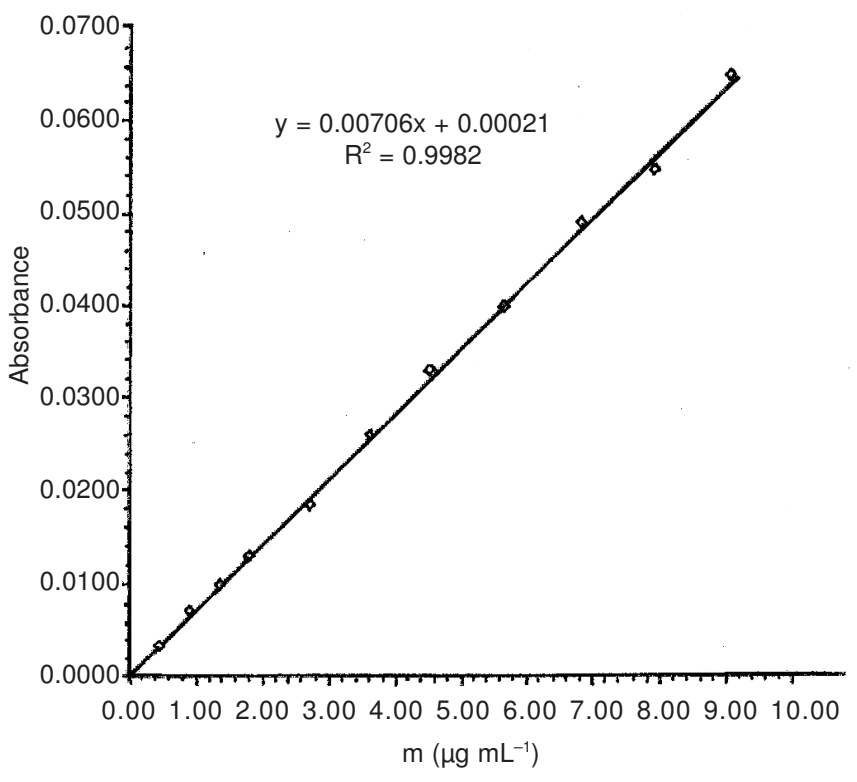

Fig. 5. Calibration curve for determination cefixime through complexation with $\mathrm{Cu}(\mathrm{II})$ in acetate buffer at $\mathrm{pH} 7.8$ in optimal conditions $(\ell=1$ $\mathrm{cm})$

Analytical results: Spectrophotometric determination of cefixime through complexation with $\mathrm{Cu}$ (II) in acetate buffer at $\mathrm{pH} 7.8$ in optimal conditions using calibration curve was applied. The results, which summarized in Table- 2 showed that, the determined concentration of cefixime was rectilinear over the range of 0.453 to $9.069 \mu \mathrm{g} \mathrm{mL}^{-1}$ with relative standard deviation (RSD) was not than $4.8 \%$. The limit of detection (LOD) and limit of quantification (LOQ) was found to be 0.072 $\mu \mathrm{g} \mathrm{mL} L^{-1}$ and $0.22 \mu \mathrm{g} \mathrm{mL}^{-1}$, respectively. The proposed method was validated statistically and through recovery studies. The method was successfully applied for the determination of cefixime in pure and dosage form with percent recoveries from 98.00 to $101.50 \%$. The results obtained from the proposed method have been compared with the official HPLC method ${ }^{6}$ and good agreement was found between them.

\begin{tabular}{|c|c|}
\hline \multicolumn{2}{|c|}{$\begin{array}{c}\text { TABLE-1 } \\
\text { THE OPTIMUM PARAMETERS ESTABLISHED FOR } \\
\text { SPECTROPHOTOMETRIC DETERMINATION OF CEFIXIME } \\
\text { IN PURE FORM THROUGH COMPLEXATION WITH } \\
\text { Cu(II) IN ACETATE BUFFER AT pH7.8 }\end{array}$} \\
\hline Parameters & Operating modes \\
\hline Time of maximum colour intensity & $40-60 \min$ \\
\hline$\lambda_{\max }$ of complex & $546 \mathrm{~nm}$ \\
\hline$\lambda_{\text {isosbestic, } 1}$ & $274 \mathrm{~nm}$ \\
\hline$\lambda_{\text {isosbestic, } 2}$ & $314 \mathrm{~nm}$ \\
\hline $\mathrm{pH}$ & 7.8 \\
\hline Buffer solution & $0.4 \mathrm{M} \mathrm{NaCH}_{3} \mathrm{COO}$ \\
\hline Solvent & Methanol: water $1: 1$ \\
\hline Temperature of solution & $30 \pm 0.5^{\circ} \mathrm{C}$ \\
\hline Concentration of $\mathrm{Cu}(\mathrm{II})$ & $\geq 10 \mathrm{C}_{\text {cefixime }}$ \\
\hline Beer's law limit, $\mu \mathrm{g} \mathrm{mL}^{-1}$ & $0.453-9.069$ \\
\hline $\mathrm{LOD}(3.3 \mathrm{SD}), \mu \mathrm{g} \mathrm{mL}^{-1}$ & 0.072 \\
\hline $\mathrm{LOQ}(10 \mathrm{SD}), \mu \mathrm{g} \mathrm{mL}^{-1}$ & 0.22 \\
\hline \multicolumn{2}{|l|}{ Regression equation: } \\
\hline Slope & 0.00706 \\
\hline Intercept & 0.00021 \\
\hline Correlation coefficient $\left(\mathrm{R}^{2}\right)$ & 0.9982 \\
\hline $\operatorname{RSD}(\%)$ & 4.8 \\
\hline
\end{tabular}

\begin{tabular}{|c|c|c|c|c|c|}
\hline \multicolumn{6}{|c|}{$\begin{array}{c}\text { TABLE-2 } \\
\text { SPECTROPHOTOMETRIC DETERMINATION OF CEFIXIME IN } \\
\text { PURE FORM THROUGH COMPLEXATION WITH Cu(II) IN } \\
\text { ACETATE BUFFER AT pH } 7.8\end{array}$} \\
\hline $\begin{array}{c}\mathrm{x}_{\mathrm{i}}, \\
\mu \mathrm{g} \mathrm{mL} \mathrm{L}^{-1} \\
\text { (taken) }\end{array}$ & $\begin{array}{l}* \overline{\mathrm{X}} \\
\mu \mathrm{g} \mathrm{mL}^{-1} \\
\text { (found) }\end{array}$ & $\begin{array}{c}\mathrm{SD} \\
\mu \mathrm{g} \mathrm{mL}^{-1}\end{array}$ & $\begin{array}{l}\frac{S D}{\sqrt{n}} \\
\mu \mathrm{g} \mathrm{mL}\end{array}$ & $\begin{array}{l}\bar{x} \pm \frac{t \cdot S D}{\sqrt{n}} \\
\mu \mathrm{gmL} \mathrm{mL}^{-1}\end{array}$ & $\begin{array}{l}\text { RSD } \\
(\%)\end{array}$ \\
\hline 0.4534 & 0.454 & 0.022 & 0.0098 & $0.454 \pm 0.027$ & 4.8 \\
\hline 0.9069 & 0.908 & 0.042 & 0.019 & $0.908 \pm 0.052$ & 4.6 \\
\hline 1.3604 & 1.36 & 0.061 & 0.027 & $1.36 \pm 0.076$ & 4.5 \\
\hline 1.8138 & 1.81 & 0.078 & 0.035 & $1.81 \pm 0.097$ & 4.3 \\
\hline 2.7207 & 2.70 & 0.11 & 0.050 & $2.70 \pm 0.14$ & 4.1 \\
\hline 3.6276 & 3.63 & 0.15 & 0.065 & $3.64 \pm 0.18$ & 4.0 \\
\hline 4.5345 & 4.54 & 0.17 & 0.075 & $4.54 \pm 0.21$ & 3.7 \\
\hline 5.6681 & 5.67 & 0.20 & 0.089 & $5.67 \pm 0.25$ & 3.5 \\
\hline 6.8018 & 6.82 & 0.23 & 0.101 & $6.82 \pm 0.28$ & 3.3 \\
\hline 7.9354 & 7.91 & 0.25 & 0.110 & $7.91 \pm 0.30$ & 3.1 \\
\hline 9.0690 & 9.08 & 0.27 & 0.122 & $9.08 \pm 0.34$ & 3.0 \\
\hline
\end{tabular}

Applications: Many applications for the determination of cefixime in some Syrian pharmaceutical preparations with a spectrophotometric method through complexation with $\mathrm{Cu}$ (II) in acetate buffer at pH 7.8 in optimal conditions were proposed. Regression equations and correlation coefficients were included in Table-3. Standard addition curves for determination of cefixime in different Syrian pharmaceutical preparations 
TABLE-3

REGRESSION EQUATIONS AND CORRELATION COEFFICIENTS FOR SPECTROPHOTOMETRIC DETERMINATION OF CEFIXIME IN SYRIAN PHARMACEUTICALS THROUGH COMPLEXATION WITH Cu(II) IN ACETATE BUFFER AT pH $7.8\left(\mathrm{~m}^{\prime}=\right.$ INTERCEPT/SLOPE, $\left.\mu \mathrm{g} \mathrm{mL}{ }^{-1}\right)$

\begin{tabular}{|c|c|c|c|}
\hline \multirow{2}{*}{ Pharmaceutical preparations } & \multicolumn{3}{|c|}{ Operating modes } \\
\hline & Regression equations $^{*}$ & Correlation coefficients & Amount of cefixime $(\mathrm{m}), \mathrm{mg} / \mathrm{tab}$. or caps. \\
\hline Bioxime (400 mg/tab) & $y=0.00705 x+0.011365$ & $\mathrm{R}^{2}=0.9978$ & $\mathrm{~m}_{\text {cefixime/tbl. }}=250 \mathrm{~m}^{\prime}=403$ \\
\hline Cefix (400 mg/caps.) & $y=0.00706 x+0.011437$ & $\mathrm{R}^{2}=0.9981$ & $\mathrm{~m}_{\text {cefixime } / \text { caps. }}=250 \mathrm{~m}^{\prime}=405$ \\
\hline Cifime (400 mg/caps.) & $y=0.00706 x+0.011353$ & $\mathrm{R}^{2}=0.9980$ & $\mathrm{~m}_{\text {cefixime/caps. }}=250 \mathrm{~m}^{\prime}=402$ \\
\hline Supraxime (400 mg/tab.) & $y=0.00705 x+0.011449$ & $\mathrm{R}^{2}=0.9979$ & $\mathrm{~m}_{\text {cefixime/caps. }}=250 \mathrm{~m}^{\prime}=406$ \\
\hline Cifime (200 mg/tab.) & $y=0.00705 x+0.005584$ & $\mathrm{R}^{2}=0.9975$ & $\mathrm{~m}_{\text {cefixime/tbl. }}=250 \mathrm{~m}^{\prime}=198$ \\
\hline
\end{tabular}

TABLE-4

SPECTROPHOTOMETRIC DETERMINATION OF CEFIXIME IN SYRIAN PHARMACEUTICALS THROUGH COMPLEXATION WITH Cu(II) IN ACETATE BUFFER AT pH 7.8

\begin{tabular}{|c|c|c|c|c|}
\hline Commercial name & Contents & $\overline{\mathrm{X}}$ (mg/tab. or caps.) & $\operatorname{RSD}(\%)$ & Recovery $(\%)$ \\
\hline Bioxime, Ctd. tab. Shifa pharmaceutical industries, Aleppo-Syria & $400 \mathrm{mg} / \mathrm{tab}$ & 403 & 4.5 & 100.75 \\
\hline Cefix, Ctd. caps. Alpha, Aleppo pharmaceutical industries, Aleppo-Syria & $400 \mathrm{mg} / \mathrm{caps}$. & 405 & 4.3 & 101.25 \\
\hline Cifime, Ctd. caps. Delta for medicaments, Aleppo-Syria & $400 \mathrm{mg} / \mathrm{caps}$. & 402 & 4.3 & 100.5 \\
\hline Supraxime Asia pharmaceutical industries, Aleppo-Syria & $400 \mathrm{mg} / \mathrm{tab}$ & 406 & 4.4 & 101.50 \\
\hline Cifime, Ctd. tab. Delta for medicaments, Aleppo-Syria & $200 \mathrm{mg} / \mathrm{tab}$. & 196 & 4.6 & 98.00 \\
\hline
\end{tabular}

were used. The amount of cefixime in one tablet, or one capsule by $\mathrm{mg} / \mathrm{tab}$., or mg/caps., (m) calculated from the following relationship: $m=h . m^{\prime}$, where: $m$ ' is the amount of cefixime in tablet, or capsule, calculated from the standard additions curve according to the following regression equation: $y=a \cdot x+b$;

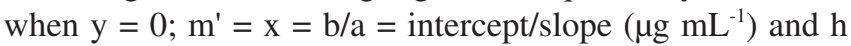
conversion factor is equal to 250 for all pharmaceuticals \{ cefix, cifime (capsule), bioxime, supraxime and cifime (tablet) $\}$. The results of quantitative analysis for cefixime in some Syrian pharmaceutical preparations were calculated using the standard additions method were summarized in Table-4.

\section{Conclusion}

Spectrophotometric determination of cefixime in pure and its Syrian pharmaceutical formations through complexation with $\mathrm{Cu}(\mathrm{II})$ in acetate buffer at $\mathrm{pH}=7.8$ has been developed. The maximum absorbance of the coloured complex occurred at $\lambda=546 \mathrm{~nm}$ and the molar absorptivity is $3.28 \times 10^{3} \mathrm{~L} \mathrm{~mol}^{-1}$ $\mathrm{cm}^{-1}$. Reaction conditions have been optimized to obtain the complex. The linear range of the calibration curve was 0.453 - $9.069 \mu \mathrm{g} \mathrm{mL}^{-1}$ with correlation coefficients $\geq 0.9975$ in all cases. Overall recoveries were of the order of $98.00-101.50 \%$. The limit of detection and limit of quantification was found to be $0.075 \mu \mathrm{g} \mathrm{mL}^{-1}$ and $0.22 \mu \mathrm{g} \mathrm{mL}^{-1}$, respectively. The proposed method was simple, economic, accurate and successfully applied to the determination of cefixime in pharmaceutical formulations and the results obtained agree well with the contents stated on the labels. The results obtained by this method were validated by HPLC ${ }^{6}$.

\section{REFERENCES}

1. M.J. O' Neil, The Merck Index: An Encyclopedia of Chemicals, Drugs and Biologicals, $14^{\text {th }}$ Ed. New Jersey: Published by Merck Research Laboratories, Division of Merck and Co., Inc. Whitehouse station: p. 1924 (2006).

2. D. Agbaba, S. Eric, K. Karljikovic-Rajic, S. Vladimirov and D. ZivanovStakic, Spectrosc. Lett., 30, 309 (1997).

3. A.F.M. El-Walily, A.A. Gazy, S.F. Belal and E.F. Khamis, J. Pharm. Biomed. Anal., 22, 385 (2000).

4. F. Al-Momani, J. Pharm. Biomed. Anal., 25, 751 (2001).

5. D.G. Shankar, K. Sushma, R.V. LAkshmi, M.N. Reddy, T.K. Murthy and Y. Rao Srinivasa, Indian Drugs, 38, 617 (2001).

6. P.B. Shah and P. Kilambi, J. AOAC Int., 89, 987 (2006).

7. S.R. El-Shaboury, F.A. Mohamed, G.A. Saleh and A.H. Rageh, Nat. Sci., 2, 432 (2010).

8. A.H. Rageh, S.R. El-Shaboury, G.L.A. Saleh and F.A. Mohamed, Nat. Sci., 2, 828 (2010).

9. B.S. Virupaxappa, K.H. Shivaprasad and M.S. Latha, Int. J. Chem. Eng. Res., 2, 23 (2010).

10. R. Kumar, P. Singh and H. Singh, Int. J. Pharm. Pharm. Sci., 3, 178 (2011).

11. J. Shah, M.R. Jan and S.S. Inayatullah, J. Fluoresc., 21, 589 (2011).

12. S.K. Patel and N.J. Patel, Int. Res. J. Pharm., 2, 145 (2011).

13. P.L.A. Satish, P.U. Paresh and P.J. Natavarlal, Int. Res. J. Pharm., 2 105 (2011).

14. M. Cesme, D. Tarinc and A. Golcu, Pharmaceuticals, 4, 964 (2011).

15. O.A. Adegoke and M.O. Quadri, Arabian J. Chem., (2012) In press.

16. V.P. Patil, A.D. Gaikwad, V.S. Kulkarni, S.J. Devdhe and S.H. Kale, Inventi Rapid: Pharm. Anal. Qual. Assur., Article ID Inventi:ppaqa/ 269/12 (2012). 